\title{
Catalytic reaction of methane with carbon dioxide over supported palladium
}

\author{
A. Erdöhelyi, J. Cserényi, E. Papp, F. Solymosi* \\ Institute of Solid State and Radiochemistry, A. Jozsef University and Reaction Kinetics Research Group of the \\ Hungarian Academy of Sciences ${ }^{\dagger}$, P.O. Box 168, H-6701 Szeged, Hungary
}

(Received 30 July 1993, revised manuscript received 11 October 1993)

\begin{abstract}
The reforming of methane with carbon dioxide has been investigated at $673-773 \mathrm{~K}$ on supported palladium catalysts in a fixed-bed continuous-flow reactor. In addition, the dissociation of carbon dioxide and methane, and the reactivity of the surface carbon formed have also been examined. The dissociation of carbon dioxide, detected by infrared spectroscopy, occurred at the lowest temperature, $373 \mathrm{~K}$, on $\mathrm{Pd} / \mathrm{TiO}_{2}$. It was greatly promoted by the presence of methane. The decomposition of methane at the temperature of the $\mathrm{CH}_{4}+\mathrm{CO}_{2}$ reaction (ca. $773 \mathrm{~K}$ ) proceeded initially at a high rate yielding hydrogen and small amounts of ethane and ethene. The deposition of surface carbon was also observed, which was hydrogenated only above $720 \mathrm{~K}$. The reaction between carbon dioxide and methane occurred rapidly above $673 \mathrm{~K}$ to give carbon monoxide and hydrogen with a ratio of 1.3 1.7. Very little carbon was deposited during the reaction of a stoichiometric gas mixture. Kinetic parameters of the reaction were determined and a possible reaction mechanism is proposed.
\end{abstract}

Key words: carbon dioxide hydrogenation; kinetics; methane reforming; palladium

\section{Introduction}

Great efforts have recently being paid to the transformation of carbon dioxide and methane, the cheapest carbon-containing materials, into more valuable compounds in catalytic reactions [1-3]. One of the means of achieving this goal is to react carbon dioxide and methane with each other and produce synthesis gas [4-13]

$$
\mathrm{CH}_{4}+\mathrm{CO}=2 \mathrm{CO}+2 \mathrm{H}_{2}
$$

*Corresponding author. Tel./fax. ( + 36-62) 322378, e-mail H3925REA@ELLA.HU

${ }^{+}$These laboratories are part of the Center for Catalysis, Surface and Material Science at the University of Szeged. 
or even more valuable substances. This reaction has been commercialized as the Calcor process [4]. One of the most effective catalysts for this process is supported rhodium [5].

The high efficiency of rhodium was confirmed by our recent comparative study of alumina-supported platinum metals, when the rate of carbon dioxide reforming with methane was related to the number of surface metal atoms [11,12]. In the present paper, the $\mathrm{CO}_{2}+\mathrm{CH}_{4}$ reaction is investigated on supported palladium which is a good catalyst for the reverse shift reaction $[14,15]$. Great attention is paid to the effects of the support and to the identification of surface intermediates in the low-temperature interaction and high-temperature reaction of carbon dioxide and methane.

\section{Experimental}

\section{Materials}

The catalysts were prepared by impregnating the support with a solution of $\mathrm{PdCl}_{2}$ salts to yield a nominal $1 \mathrm{wt} .-\%$ or $5 \%$ metal. The following oxides were used: $\mathrm{Al}_{2} \mathrm{O}_{3}$ (Degussa $\mathrm{P} 110 \mathrm{Cl}, 100 \mathrm{~m}^{2} / \mathrm{g}$ ), $\mathrm{TiO}_{2}$ (Degussa P25, $150 \mathrm{~m}^{2} / \mathrm{g}$ ), $\mathrm{SiO}_{2}$ (Cab-O-Sil, $200 \mathrm{~m}^{2} / \mathrm{g}$ ), and MgO (DAB $6,170 \mathrm{~m}^{2} / \mathrm{g}$ ). For catalytic studies small fragments of slightly compressed pellets were used. The size of the fragments was $2 \times 2 \times 0.5 \mathrm{~mm}$. For IR spectroscopic measurements the powdered material was pressed into a $10 \times 30 \mathrm{~mm}$ self-supporting disk.

Before the measurements the catalysts were oxidized for $30 \mathrm{~min}$ and reduced for $60 \mathrm{~min}$ at $773 \mathrm{~K}$ in situ. After oxidation and reduction the sample was evacuated or flushed with helium or nitrogen for $15 \mathrm{~min}$.

The gases used were initially of commercial purity. The carbon dioxide was further purified by fractional distillation. Helium (99.995\%) and nitrogen $(99.95 \%)$ were deoxygenated with an oxy-trap. The other impurities were adsorbed by a $5 \mathrm{~A}$ molecular sieve at the temperature of liquid air.

\section{Methods}

The same experimental methods were used as described in our previous papers $[11,12]$. The decomposition of methane and the $\mathrm{CH}_{4}+\mathrm{CO}_{2}$ reaction were carried out in a fixed-bed continuous flow reactor made from a 15-mm I.D. quartz tube. The amount of catalyst used was $0.5 \mathrm{~g}$, the flow rate of reactant gases were $40 \mathrm{ml} / \mathrm{min}$ and the space velocities were $6000 \mathrm{~h}^{-1}$. Helium or nitrogen was used as diluent to determine the partial order of carbon monoxide and hydrogen formation. The exit gases were analyzed gas chromatographically (Hewlett-Packard 5890 and 5710) on a Porapack QS column. The amounts of $\mathrm{CO}, \mathrm{CO}_{2}$ and $\mathrm{CH}_{4}$ were determined in the helium carrier gas. Hydrogen was detected simultaneously in a separate gas chromatograph in a nitrogen stream by a thermal conductivity detector. The gas sampling valves of the gas chromatographs were connected with each other.

The conversion of carbon dioxide and methane were defined as the converted carbon dioxide or methane per total amount of carbon dioxide or methane. The methane and carbon dioxide consumption were calculated from the products, taking into account the following equation: 


$$
\mathrm{CO}_{2}+\mathrm{CH}_{4}=2 \mathrm{CO}+2 \mathrm{H}_{2} \text { and } \mathrm{H}_{2}+\mathrm{CO}_{2}=\mathrm{CO}+\mathrm{H}_{2} \mathrm{O}
$$

A pulse reactor was also employed (8-mm O.D. quartz tube), which was incorporated between the sample inlet and the column of the gas chromatograph (Hewlett-Packard 5710). One pulse contained $16.3 \mu \mathrm{mol}$ gases. Usually a $0.3-\mathrm{g}$ sample was used and the dead volume of the reactor was minimized with quartz beads. The reactor was heated by an external oven.

The temperature-programmed reaction (TPR) experiments (for the determination of surface carbon formed in methane decomposition) were carried out in the pulse reactor. After production of carbon, and flushing of the surface with helium at the temperature at which carbon was formed, the samples were cooled in a helium flow to $323 \mathrm{~K}$. The flow was then switched to hydrogen, the sample was heated at $12 \mathrm{~K} \mathrm{~min}^{-1}$, and the hydrocarbons formed were analyzed.

The infrared spectroscopic studies were made in a vacuum cell using self supporting wafers which underwent the same pretreatment as the catalyst. The spectra were recorded with a Specord M 80 IR Zeiss Jena double-beam spectrometer.

The dispersions of the supported metals were determined by $\mathrm{H}_{2}-\mathrm{O}_{2}$ titration at $298 \mathrm{~K}$ using the pulse technique $[14,15]$.

\section{Results}

\section{Dissociation of carbon dioxide}

First, we examined the adsorption and dissociation of carbon dioxide on supported palladium. The most sensitive method for following these processes is IR spectroscopy, as carbon monoxide, the primary product of the dissociation is strongly bonded to the palladium. In accordance with our previous measurements [14,15], carbon dioxide does not adsorb on supported palladium at room temperature and no dissociation can be detected on the palladium surface free of adsorbed hydrogen. The same was observed for palladium single crystals [ 16-19]. However, the dissociation occurred at elevated temperatures, 473$673 \mathrm{~K}$ on supported palladium samples. The dissociation is indicated by the appearance of weak absorption bands in the region of $1750-2080 \mathrm{~cm}^{-1}$ due to adsorbed carbon monoxide with a different coordination. A weak carbon monoxide band at $1892 \mathrm{~cm}^{-1}$, indicative of the dissociation of carbon dioxide, appeared at the lowest temperature, $373 \mathrm{~K}$, in the IR spectrum of $\mathrm{Pd} / \mathrm{TiO}_{2}$ (Fig. 1). The intensity of the band remained practically unaltered up to $473 \mathrm{~K}$, and disappeared above $573 \mathrm{~K}$. On $\mathrm{Pd} / \mathrm{Al}_{2} \mathrm{O}_{3}$ two carbon monoxide bands were observed at 1770 and $1870 \mathrm{~cm}^{-1}$ at $473 \mathrm{~K}$. The intensities of these bands increased with increasing the adsorption temperature of carbon dioxide. On $\mathrm{Pd} / \mathrm{SiO}_{2}$ weak carbon monoxide bands, absorbing at 1810 and $1870 \mathrm{~cm}^{-1}$ (Fig. 1), were detected at and above 473 $\mathrm{K}$. On increasing the temperature to $523 \mathrm{~K}$, the latter peak shifted to $1910 \mathrm{~cm}^{-1}$, and above $623 \mathrm{~K}$ new absorption bands at 1970 and $2079 \mathrm{~cm}^{-1}$ appeared. At the same time, the band at $1870 \mathrm{~cm}^{-1}$ also shifted to higher wavenumbers. Spectra obtained for different samples are shown in Fig. 1.

The dissociation of carbon dioxide was also studied by the pulse method at $773 \mathrm{~K}$, at the 


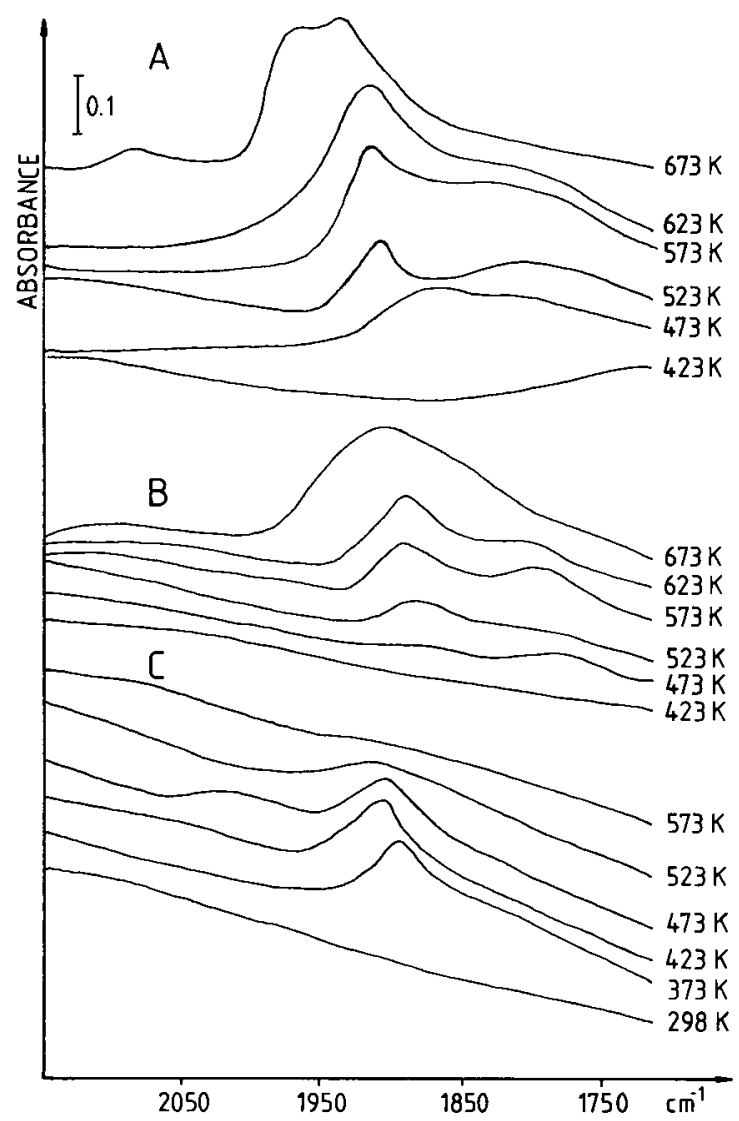

Fig. 1. Infrared spectra of supported Pd following the adsorption of carbon dioxide ( 50 Torr) at different temperatures. (A) $5 \% \mathrm{Pd} / \mathrm{SiO}_{2}$, (B) $5 \% \mathrm{Pd} / \mathrm{Al}_{2} \mathrm{O}_{3}$, (C) $5 \% \mathrm{Pd} / \mathrm{TiO}_{2}$. Spectra were always taken at $300 \mathrm{~K}$.

catalytic reaction temperature of carbon dioxide with methane. The amount of carbon monoxide formed in the dissociation of carbon dioxide decreased in all cases as a function of pulse number. The highest amount of carbon monoxide was produced on $\mathrm{Pd} / \mathrm{TiO}_{2}$. On $\mathrm{Pd} / \mathrm{SiO}_{2}$ only traces of carbon monoxide were detected. The results are shown in Fig. 2. As the carbon monoxide formed can dissociate to carbon at such a high temperature, an attempt was made to determine the amount of surface carbon present: the catalyst was treated with oxygen pulses and the amount of carbon dioxide was determined. We found only a very small amount of carbon $(0.01-0.5 \mu \mathrm{mol} / \mathrm{g}$ catalyst $)$.

\section{Decomposition of methane and the reactions of the formed carbon}

The decomposition of methane was investigated under the experimental conditions of the $\mathrm{CO}_{2}+\mathrm{CH}_{4}$ reaction. The formation of hydrogen, ethane and ethylene was established (Fig. 3). The amount of hydrogen greatly exceeded that of $\mathrm{C}_{2}$ hydrocarbons on all catalyst 


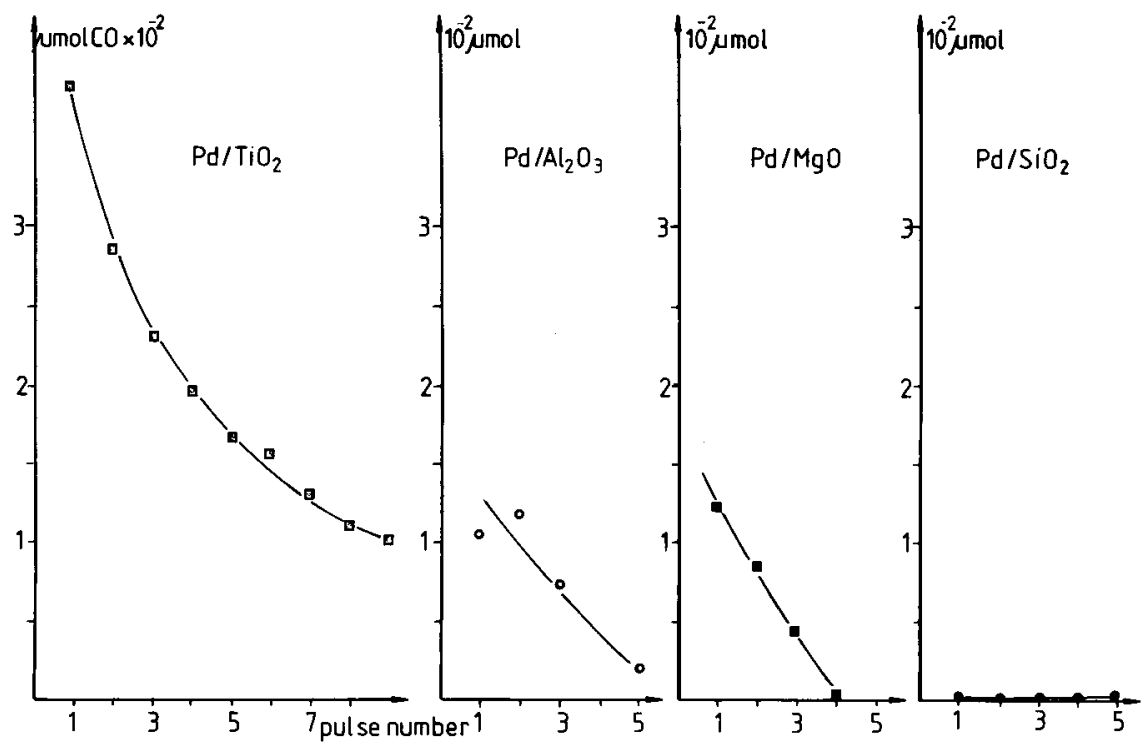

Fig. 2. The amount of $\mathrm{CO}$ formed in the dissociation of carbon dioxide pulses on different Pd samples ( $1 \% \mathrm{Pd})$ at $773 \mathrm{~K}$. One pulse contained $16.3 \mu \mathrm{mol}$ of $\mathrm{CO}_{2}$.
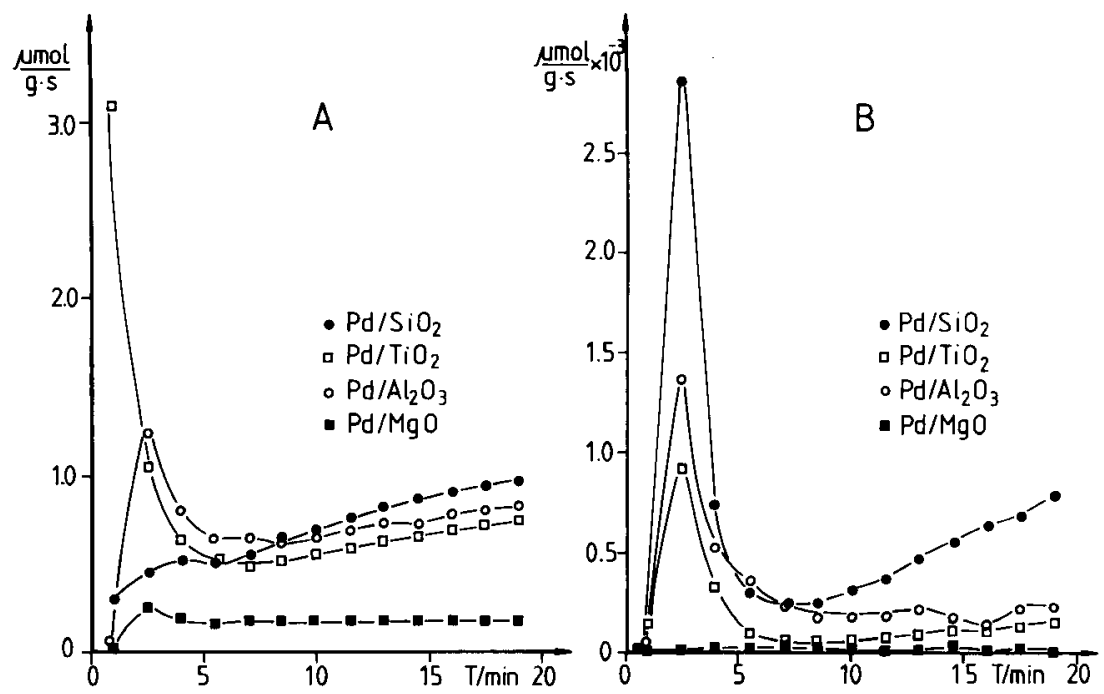

Fig. 3. Rates of $\mathrm{H}_{2}$ (A) and $\mathrm{C}_{2} \mathrm{H}_{6}$ (B) formation in the decomposition of $\mathrm{CH}_{4}$ on supported $\mathrm{Pd}$ ( $5 \%$ Pd) at 773 K. Flow-rate of $\mathrm{N}_{2}+\mathrm{CH}_{4}(12.5 \%): 40 \mathrm{ml} / \mathrm{min}$. Sample mass: $100 \mathrm{mg}$.

samples (Table 1). This suggests an accumulation of carbonaceous residue on the catalysts during methane decomposition. In the case of the most active $\mathrm{Pd} / \mathrm{TiO}_{2}$ catalyst the initial decomposition of methane, calculated from the hydrogen evolution, reached a value of 
Table 1

Amount of ethane and hydrogen formed in the decomposition of methane on supported palladium catalysts at 773 $\mathrm{K}$ in $20 \mathrm{~min}^{\prime \prime}$

\begin{tabular}{llll}
\hline Catalysts & $\begin{array}{l}\mathrm{C}_{2} \mathrm{H}_{6} \\
(\mu \mathrm{mol} / \mathrm{g})\end{array}$ & $\begin{array}{l}\mathrm{H}_{2} \\
(\mu \mathrm{mol} / \mathrm{g})\end{array}$ & $\begin{array}{l}\mathrm{C}_{\mathrm{s}}{ }^{c} \\
(\mu \mathrm{mol} / \mathrm{g})\end{array}$ \\
\hline $5 \% \mathrm{Pd} / \mathrm{TiO}_{2}$ & 0.179 & 904 & 342 \\
$5 \% \mathrm{Pd} / \mathrm{Al}_{2} \mathrm{O}_{3}$ & 0.3 & 786 & 386 \\
$5 \% \mathrm{Pd} / \mathrm{SiO}_{2}$ & $1.01^{b}$ & 764 & 185 \\
$5 \% \mathrm{Pd} / \mathrm{MgO}$ & $3 \times 10^{-4}$ & 183 & 89 \\
\hline
\end{tabular}

${ }^{a} 12.5 \%$ methane in nitrogen was used as reactant; the flow rate was $40 \mathrm{ml} / \mathrm{min}$.

${ }^{b}$ Sum of ethane and ethylene.

'Determined from the TPR curves of the hydrogenation of surface carbon up to $1100 \mathrm{~K}$.
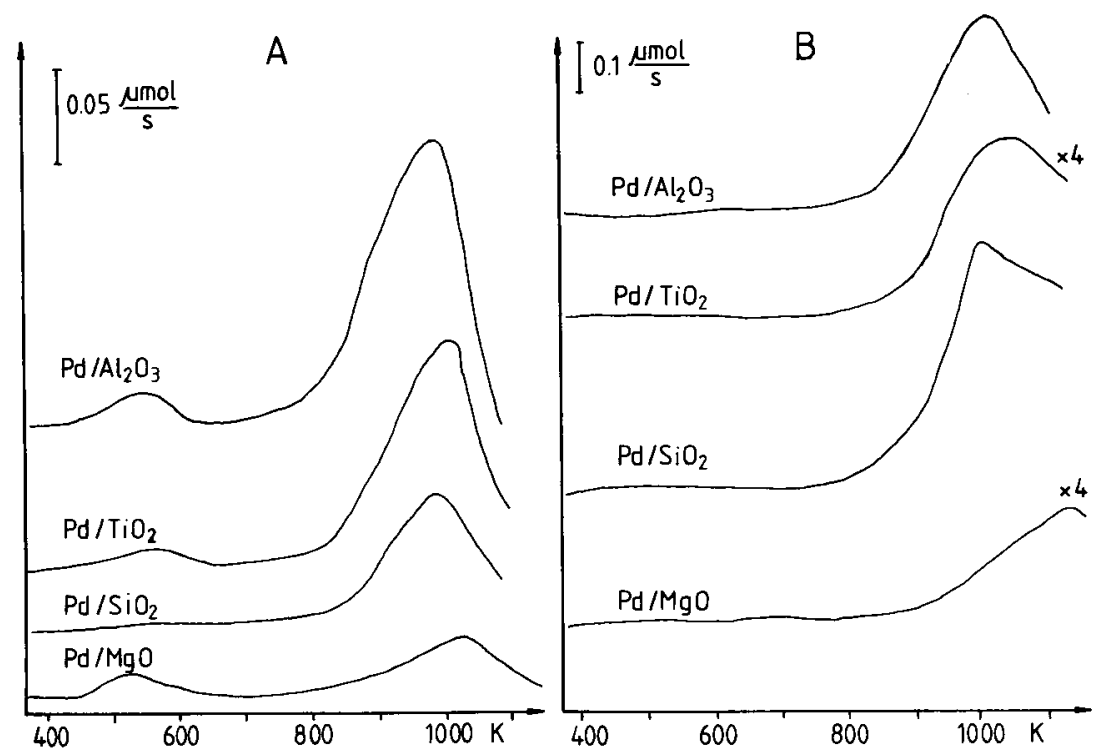

Fig. 4. Temperature-programmed reaction of carbon with $\mathrm{H}_{2}$ on supported $\mathrm{Pd}(5 \% \mathrm{Pd})$. Carbon was produced by the decomposition of pure methane at $773 \mathrm{~K}$ for $1 \mathrm{~min}$ (A) and $15 \mathrm{~min}$ (B). Flow-rate of methane: $200 \mathrm{ml} / \mathrm{min}$.

$4.4 \%$, but it decayed to $0.78 \%$ after $10 \mathrm{~min}$. In this stage the activity of palladium samples was practically the same, with the exception of $\mathrm{Pd} / \mathrm{MgO}$, which exhibited much less catalytic effect on the decomposition of methane. The rate of ethane evolution passed through a maximum. The largest ethane formation was observed on $\mathrm{Pd} / \mathrm{SiO}_{2}$ (Fig. 3B). On this sample, the concentration of ethylene was commensurable with that of the ethane $\left(\mathrm{C}_{2} \mathrm{H}_{6} /\right.$ $\mathrm{C}_{2} \mathrm{H}_{4}$ ratio at the maximum of their formation was 2.08 ). On the other samples ethylene was only detected in the first minutes of methane decomposition.

The hydrogenation of surface carbon formed in the decomposition of methane at $773 \mathrm{~K}$ was investigated by the TPR method. Results are presented in Fig. 4 . When the catalysts were pretreated with methane at $773 \mathrm{~K}$ for a short time $(1 \mathrm{~min}, 200 \mathrm{ml}$ ), a small proportion 
of surface carbon was hydrogenated between $450-600 \mathrm{~K}$. The main reaction commenced on all samples only above $720 \mathrm{~K}, T_{\max }=980-1020 \mathrm{~K}$. It appears that the support exerts only a slight influence on the reactivity of surface carbon. When the samples were exposed to methane for $15 \mathrm{~min}$ at $773 \mathrm{~K}$, the low temperature TPR peaks were missing, but the high temperature features remained practically unaltered.

\section{$\mathrm{CH}_{4}+\mathrm{CO}_{2}$ surface interaction}

In the subsequent experiments we examined how the addition of methane to carbon dioxide influenced the dissociation of the carbon dioxide. Some selected IR spectra for $\mathrm{Pd} /$ $\mathrm{SiO}_{2}$ and $\mathrm{Pd} / \mathrm{Al}_{2} \mathrm{O}_{3}$ are displayed in Fig. 5. It can be clearly seen that on $\mathrm{Pd} / \mathrm{SiO}_{2}$ a band at $1843 \mathrm{~cm}^{-1}$ due to adsorbed carbon monoxide appears at lower temperatures $(423 \mathrm{~K})$, and with higher intensity as compared with the methane-free condition. The intensity of the

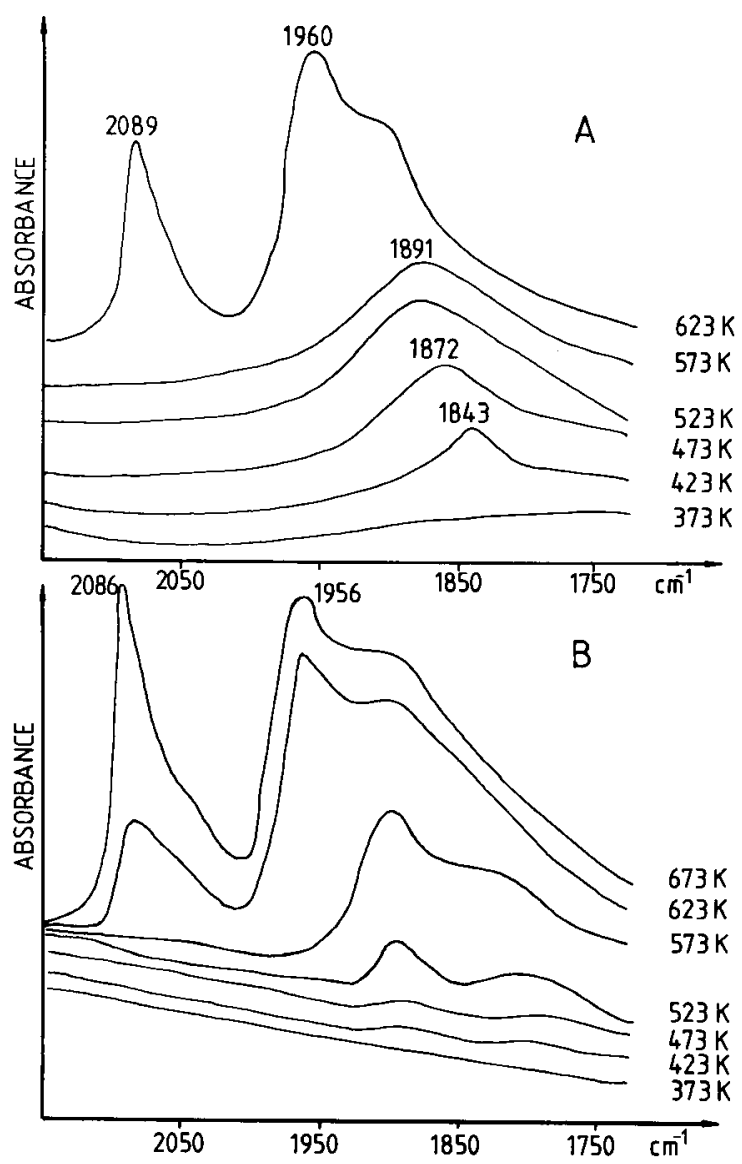

Fig. 5. Infrared spectra of supported Pd following the adsorption of $\mathrm{CO}_{2}$ and $\mathrm{CH}_{4}$ mixture at 50 Torr each at different temperatures. (A) $5 \% \mathrm{Pd} / \mathrm{SiO}_{2}$ and (B) $5 \% \mathrm{Pd} / \mathrm{Al}_{2} \mathrm{O}_{3}$. 
band increased, and its position shifted to higher wavenumbers when the temperature was raised further. At $623 \mathrm{~K}$, an intense absorption band was detected at $2089 \mathrm{~cm}^{-1}$. The effect of methane was more pronounced for $\mathrm{Pd} / \mathrm{Al}_{2} \mathrm{O}_{3}$. Whereas in the absence of methane there was no indication of the high-frequency band of carbon monoxide above $2000 \mathrm{~cm}^{-1}$, in the presence of methane it appeared with high intensity at and above $623 \mathrm{~K}$.

Note that in spite of our great efforts, we did not succeed in identifying any of the absorption bands attributable to adsorbed $\mathrm{CH}_{4}$ or $\mathrm{CH}_{x}$ species in the temperature range 300 $623 \mathrm{~K}$.

\section{Reactions of methane with carbon dioxide}

The highest reaction temperature applied was $773 \mathrm{~K}$. Using a stoichiometric composition of reacting gas mixture, only a relatively slight deactivation of the catalyst samples occurred at this temperature (Fig. 6). In the case of $\mathrm{Pd} / \mathrm{SiO}_{2}$ and $\mathrm{Pd} / \mathrm{MgO}$ the $\mathrm{CO} / \mathrm{H}_{2}$ ratio increased

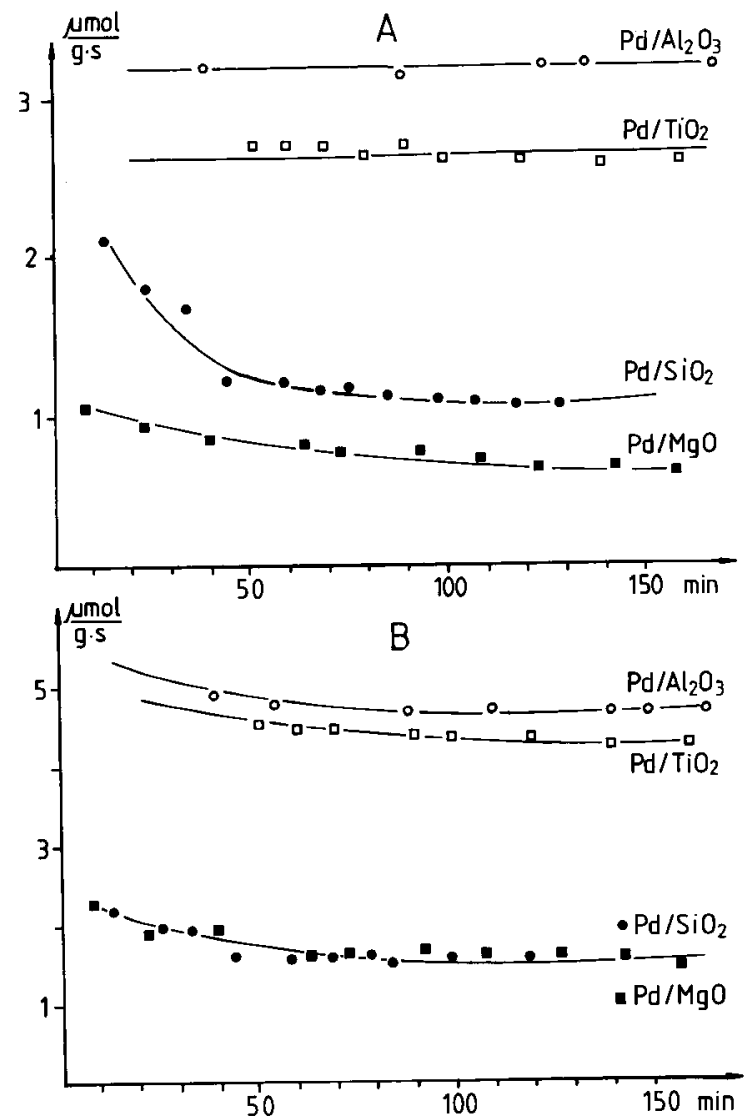

Fig. 6. Rates of $\mathrm{H}_{2}$ (A) and $\mathrm{CO}(\mathrm{B})$ formation in the $\mathrm{CO}_{2}+\mathrm{CH}_{4}$ reaction on different $\mathrm{Pd}$ samples $(1 \% \mathrm{Pd})$ at $773 \mathrm{~K}$. 
at the beginning of the reaction. On the other samples it changed only slightly. In the temperature range $673-773 \mathrm{~K}$, only traces of $\mathrm{C}_{2}$ hydrocarbons were detected. A completely different picture was obtained when the reacting gas mixture contained excess methane. In this case a dramatic decay in the initial rate was experienced.

The effect of the reactant concentration on the rate of product formation was investigated on $\mathrm{Pd} / \mathrm{SiO}_{2}$. Reproducible results were obtained only at a stoichiometric composition and in an excess of carbon dioxide. With an increase in the concentration of methane and carbon dioxide the formation of both carbon monoxide and hydrogen increased (Fig. 7). At the same time the $\mathrm{CO} / \mathrm{H}_{2}$ ratio decreased. The kinetic orders were calculated from the logarithmic plots of the various rates versus the volume percentage of the reactant of interest. The orders with respect to methane were 0.15 and 0.32 for the formation of carbon monoxide and hydrogen, respectively. The order with respect to carbon dioxide was 0.12 for carbon monoxide formation and 0.24 for hydrogen evolution.

From the temperature dependence of the rates of hydrogen and carbon monoxide production, the apparent activation energies were determined (Fig. 8). On $\mathrm{Pd} / \mathrm{TiO}_{2}$ and $\mathrm{Pd} /$ $\mathrm{Al}_{2} \mathrm{O}_{3}$, we obtained higher values for the production of hydrogen than for that of carbon monoxide; as a result, a slight decrease in the $\mathrm{CO} / \mathrm{H}_{2}$ ratio was experienced with an increase of temperature. In the case of $\mathrm{Pd} / \mathrm{MgO}$, the activation energy of carbon monoxide formation was higher than that of hydrogen, and so the $\mathrm{CO} / \mathrm{H}_{2}$ ratio increased with increasing temperature. On $\mathrm{Pd} / \mathrm{SiO}_{2}$, the two activation energies were practically the same. Kinetic data are summarized in Table 2.

In order to compare the efficiencies of the supports, we calculated the turnover frequency, the rates of hydrogen and carbon monoxide formation related to the number of surface palladium atoms. The highest specific activity was obtained for $\mathrm{Pd} / \mathrm{TiO}_{2}$, which was fol-
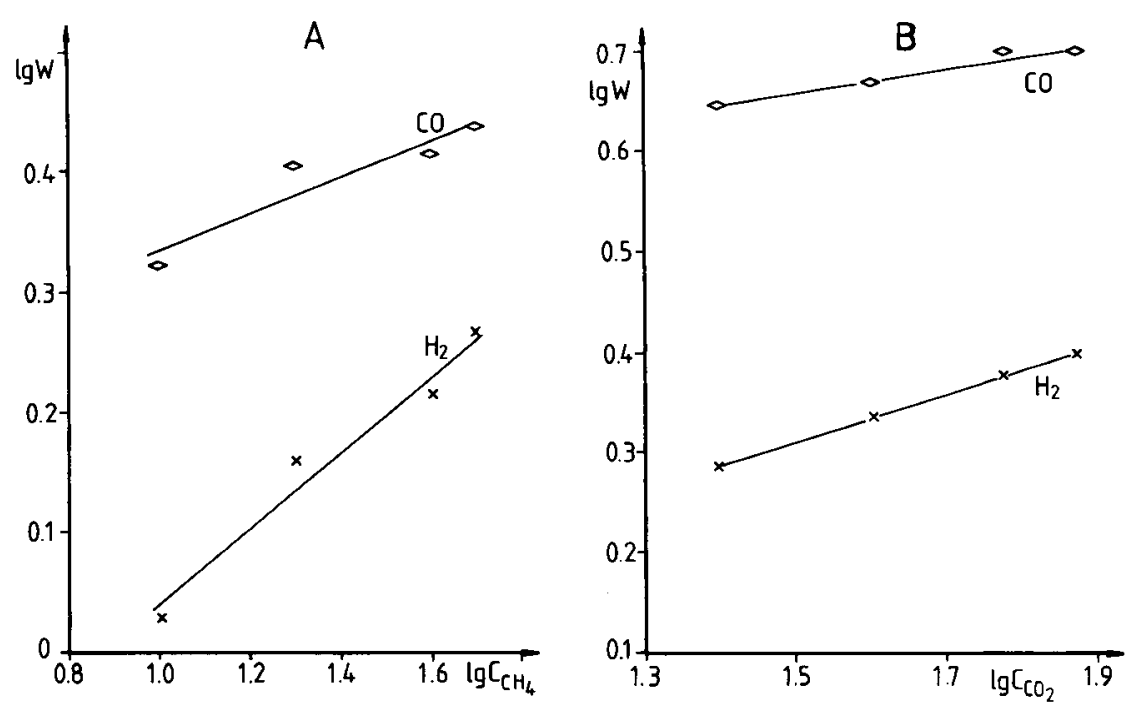

Fig. 7. Dependence of the rates $(\mathrm{w}[\mu \mathrm{mol} / \mathrm{g} \cdot \mathrm{s}])$ of product formation in $\mathrm{CH}_{4}+\mathrm{CO}_{2}$ reaction on the partial pressure of $\mathrm{CH}_{4}$ and $\mathrm{CO}_{2}$ at $773 \mathrm{~K}$. (A) Effect of $\mathrm{CH}_{4}$ partial pressure. The $\mathrm{CO}_{2}$ content was $25 \%$. (B) Effect of $\mathrm{CO}_{2}$ partial pressure. The $\mathrm{CH}_{4}$ content was $25 \%$. Inert gas $\left(\mathrm{He}\right.$ or $\mathrm{N}_{2}$ ) was used as diluent in both cases. 


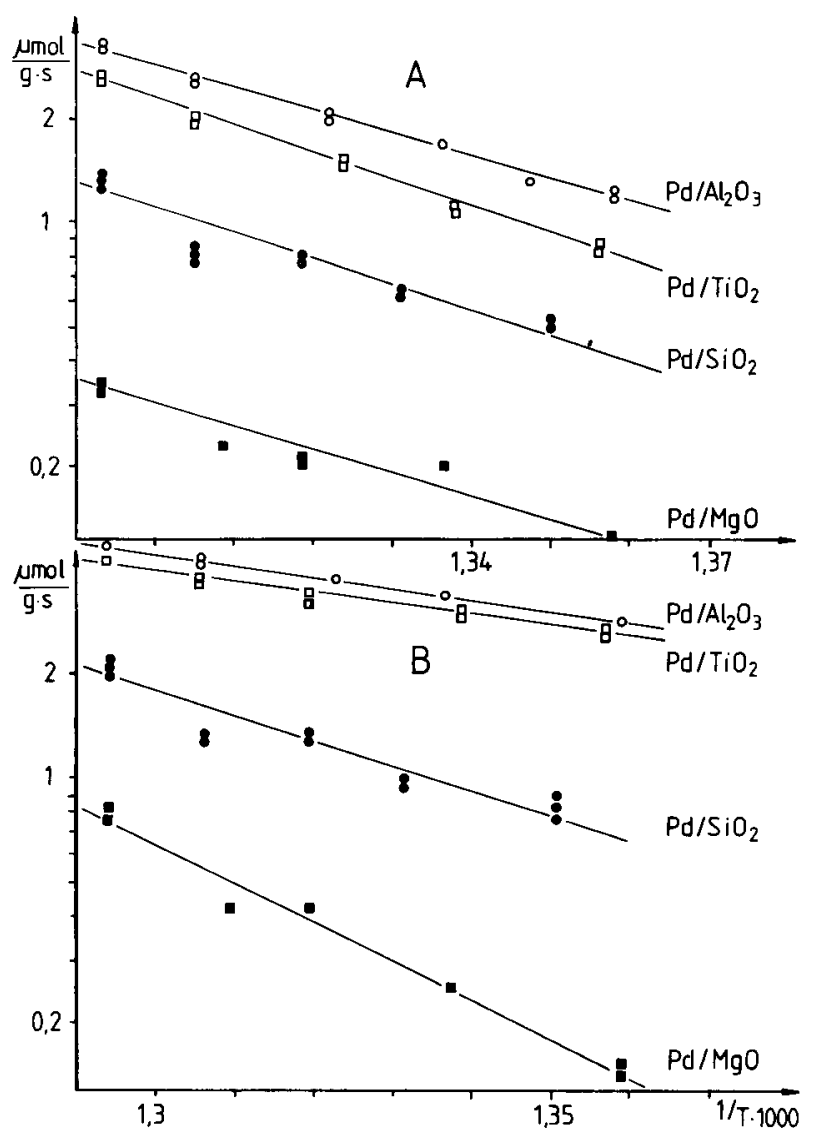

Fig. 8. Arrhenius diagrams of $\mathrm{H}_{2}$ (A) and $\mathrm{CO}$ (B) formation for different Pd samples.

lowed by $\mathrm{Pd} / \mathrm{Al}_{2} \mathrm{O}_{3}, \mathrm{Pd} / \mathrm{SiO}_{2}$, and $\mathrm{Pd} / \mathrm{MgO}$. The activity of $\mathrm{Pd} / \mathrm{TiO}_{2}$ was more than one order of magnitude higher than that of $\mathrm{Pd} / \mathrm{MgO}$ (Table 2). As the dispersity of palladium on $\mathrm{TiO}_{2}$ reduced at $773 \mathrm{~K}$, significantly decreased due to the migration of titania on the palladium ("decoration effect"), the catalytic performance of the $\mathrm{Pd} / \mathrm{TiO}_{2}$ reduced at lower temperatures was also tested. In this case, the dispersity of palladium was commensurable with those measured for other palladium samples. Although the specific activity of the $\mathrm{Pd} / \mathrm{TiO}_{2}$ was somewhat lower than that of the high temperature reduced $\mathrm{Pd} / \mathrm{TiO}_{2}$, the $\mathrm{Pd} / \mathrm{TiO}_{2}$ still remained the most effective catalyst in the $\mathrm{CH}_{4}-\mathrm{CO}_{2}$ reaction. Note that the supports alone were completely inactive for this reaction up to $823 \mathrm{~K}$.

Examination of catalyst samples after the $\mathrm{CO}_{2}+\mathrm{CH}_{4}$ reaction revealed only a relatively small amount of carbon. The carbon was determined in the form of carbon dioxide by treating the catalysts with oxygen at $723-823 \mathrm{~K}$. The highest value was obtained for $\mathrm{Pd} /$ $\mathrm{SiO}_{2}$, but even in this case the ratio of $\mathrm{C} / \mathrm{Pd}_{\text {surf }}$ was only 0.06 . On other palladium samples only traces of carbon dioxide were detected. 
Table 2

Some characteristic data for the $\mathrm{CO}_{2}+\mathrm{CH}_{4}$ reaction on different supported palladium catalysts at $773 \mathrm{~K}^{a}$

\begin{tabular}{|c|c|c|c|c|c|c|c|c|c|c|c|c|}
\hline \multirow[t]{3}{*}{ Catalyst } & \multirow{3}{*}{$\begin{array}{l}D^{b} \\
(\%)\end{array}$} & \multicolumn{2}{|c|}{$\begin{array}{l}\text { Conversion } \\
(\%)\end{array}$} & \multicolumn{4}{|c|}{ Formation rate } & \multirow{3}{*}{$\mathrm{CO} / \mathrm{H}_{2}$} & \multirow{3}{*}{$\begin{array}{l}E_{\mathrm{CH}_{4}} \\
(\mathrm{~kJ} \mathrm{~mol})\end{array}$} & \multirow{3}{*}{$\begin{array}{l}E_{\mathrm{CO}} \\
(\mathrm{kJ} \mathrm{mol})\end{array}$} & \multirow{3}{*}{$\begin{array}{l}E_{\mathrm{H}_{2}} \\
(\mathrm{~kJ} \mathrm{~mol})\end{array}$} & \multirow{3}{*}{$\begin{array}{l}\text { Surface } \\
\text { carbon }^{d} \\
\text { C/Pd }\end{array}$} \\
\hline & & \multirow[b]{2}{*}{$\mathrm{CH}_{4}$} & \multirow[b]{2}{*}{$\mathrm{CO}_{2}$} & \multicolumn{2}{|c|}{$\mu \mathrm{mol} / \mathrm{g} \cdot \mathrm{s}$} & \multicolumn{2}{|c|}{$\begin{array}{l}\mathrm{TOF}^{\mathrm{c}} \\
\left(\mathrm{s}^{-1}\right)\end{array}$} & & & & & \\
\hline & & & & $\mathrm{CO}$ & $\mathrm{H}_{2}$ & $\mathrm{CO}$ & $\mathbf{H}_{2}$ & & & & & \\
\hline $1 \% \mathrm{Pd} / \mathrm{TiO}_{2}$ & 3.03 & 9.4 & 16.1 & 4.37 & 2.59 & 1.53 & 0.9 & 1.68 & 91.5 & 62.8 & 145.8 & $>0.001$ \\
\hline $1 \% \mathrm{Pd} / \mathrm{Al}_{2} \mathrm{O}_{3}$ & 23.2 & 8.6 & 15.0 & 4.72 & 3.16 & 0.21 & 0.14 & 1.47 & 93.1 & 62.8 & 125.7 & $>0.001$ \\
\hline $1 \% \mathrm{Pd} / \mathrm{SiO}_{2}$ & 11.6 & 4.8 & 7.4 & 1.9 & 1.3 & 0.18 & 0.12 & 1.46 & 141.2 & 141.3 & 141.1 & 0.02 \\
\hline $1 \% \mathrm{Pd} / \mathrm{MgO}$ & 10.8 & 1.4 & 2.5 & 0.76 & 0.35 & 0.07 & 0.03 & 1.50 & 113.5 & 216.9 & 129.4 & $>0.001$ \\
\hline
\end{tabular}

"The carbon dioxide and methane content of inlet gas was $50-50 \%$.

${ }^{h}$ Dispersion: the amount of surface metal atoms.

"Turnover frequency; rates related to the number of surface metal atoms.

${ }^{d}$ The amount of surface carbon formed in the first hour of the reaction. The carbon was determined in the form of carbon dioxide by treating the surface with oxygen at 773 and $873 \mathrm{~K}$.

\section{Discussion}

Let us first consider the dissociation of carbon dioxide and methane on supported palladium at the catalytic reaction temperatures.

\section{Dissociation of carbon dioxide}

The dissociation of carbon dioxide on the samples used in the present study was monitored by IR spectroscopy and by the pulse method. Carbon monoxide bands at 1810-1820, 18701910,1970 and $2079 \mathrm{~cm}^{-1}$, indicative of the dissociation of carbon dioxide, appeared only at and above $373-473 \mathrm{~K}$. The band at $1870-1910 \mathrm{~cm}^{-1}$ relates to twofold coordinated carbon monoxide, and the band at $1810-1820 \mathrm{~cm}^{-1}$ to threefold coordinated carbon monoxide [20,21]. The band at $2079 \mathrm{~cm}^{-1}$ is ascribed to the linearly bonded carbon monoxide. The band at $1970 \mathrm{~cm}^{-1}$ produced also above $623 \mathrm{~K}$, has been attributed to the carbon monoxide adsorbed on (100) planes of palladium [22,23]. The fact that the latter two bands appeared only above $623 \mathrm{~K}\left(\mathrm{Pd} / \mathrm{SiO}_{2}\right)$ may be the result of carbon monoxideinduced agglomeration or morphological changes of palladium crystallites, as was observed at high temperatures for supported rhodium samples [24-26]. Alternatively, the surface concentration of carbon monoxide at lower temperatures was low enough to produce linearly bonded carbon monoxide species.

If the temperature at which the carbon monoxide bands appear is taken as a measure of the dissociation of carbon dioxide, then the order of activity of the palladium samples is as follows: $\mathrm{Pd} / \mathrm{TiO}_{2}, \mathrm{Pd} / \mathrm{Al}_{2} \mathrm{O}_{3}, \mathrm{Pd} / \mathrm{SiO}_{2}$ and $\mathrm{Pd} / \mathrm{MgO}$. The same order of activity was found in the high-temperature dissociation (at $773 \mathrm{~K}$ ) of carbon dioxide (Fig. 2), and also in the $\mathrm{CH}_{4}-\mathrm{CO}_{2}$ reaction. Possible reasons of this order of activity are presented in the discussion of the catalytic results. 


\section{Decomposition of methane}

The dissociation of methane over a supported palladium catalyst have been observed even in the low-temperature range, $473-573 \mathrm{~K}$, when hydrogen and a small amount of ethane were produced with the deposition of surface carbon [27]. In the temperature range of the $\mathrm{CH}_{4}+\mathrm{CO}_{2}$ reaction $(673-773 \mathrm{~K}$ ), the extent of methane decomposition was greater and a much larger amount of surface carbon was produced. This led to a significant decay in the decomposition of methane, which, however, did not cease. This may mean that the carbon species formed a cluster on the palladium crystallite or migrated onto the support.

The data presented in Fig. 3 indicate that, apart from the initial stage, where $\mathrm{Pd} / \mathrm{TiO}_{2}$ exhibited high activity, there is no significant support effect in the decomposition of methane on the palladium catalyst. The same is valid for the reactivity of surface carbon produced in the decomposition of methane (Fig. 4). The carbon formed exhibited a rather low reactivity towards hydrogen, as its hydrogenation started only above $720 \mathrm{~K}$. A more reactive carbon $\left(T_{\mathrm{p}}=520-550 \mathrm{~K}\right)$ was detected only when the reaction time of the decomposition of methane (e.g. that of the carbon formation) was very short (Fig. 4). Taking into account our results obtained on the reactivity of different carbon forms over supported rhodium $[12,28,29]$, these features suggest that in the high-temperature decomposition of methane a more reactive amorphous carbon is primarily produced which is quickly transformed into a less reactive graphitic form.

\section{$\mathrm{CH}_{4}+\mathrm{CO}_{2}$ interaction}

From a comparison of the spectra presented in Figs. 1 and 5, it appears clearly that in the presence of methane the carbon monoxide bands develop at lower temperatures and at higher intensities than in the absence of methane. Accordingly, methane promotes the dissociation of carbon dioxide on supported palladium catalysts. As there was no spectral indication for the formation of any surface complexes between carbon dioxide and methane, the promotion of the dissociation of carbon dioxide is attributed to the effect of hydrogen formed in the decomposition of methane. It was demonstrated before that a small amount of hydrogen can greatly facilitate this process $[14,15]$. It is important to point out that this carbon monoxide band always appeared at lower frequencies than in the absence of methane. A down-shift of the carbon monoxide bands was also observed following the co-adsorption of the $\mathrm{H}_{2}+\mathrm{CO}_{2}$ mixture on both supported rhodium and palladium catalysts and was ascribed to the formation of a carbonyl-hydride, $\operatorname{Pd}_{x}<\mathrm{CO}$ species $[14,15,30,31]$. It is assumed that the dissociation of carbon monoxide is promoted in this surface complex $[30,31]$.

\section{Catalytic reaction between $\mathrm{CH}_{4}$ and $\mathrm{CO}_{2}$}

Although great attention is being paid to the conversion of carbon dioxide and methane to more valuable compounds, few papers have dealt with the catalytic reaction between carbon dioxide and methane [4-13], which is commercialized as the Calcor process [4].

On the palladium samples used in the present study, the $\mathrm{CH}_{4}+\mathrm{CO}_{2}$ reaction 


$$
\mathrm{CO}_{2}+\mathrm{CH}_{4}=2 \mathrm{CO}+2 \mathrm{H}_{2}
$$

proceeded with a significant conversion $(0.5 \%-16 \%)$ at $673-773 \mathrm{~K}$. Although both compounds undergo dissociation separately even at much lower temperatures, their decomposition products $\mathrm{C}, \mathrm{O}$ and $\mathrm{CO}$ terminate their reactions by covering the active areas of the palladium metal. However, when both compounds are present, particularly at high temperatures, their self-decomposition is greatly accelerated. We assume the following effects: (i) promotion of the dissociation of carbon dioxide by hydrogen, and perhaps by $\mathrm{CH}_{x}$ fragments, too, and (ii) facilitation of the dissociation of methane by adsorbed $\mathrm{O}$ formed in the decomposition of carbon dioxide, which may activate the methane molecule. Accordingly, we may count with the following reactions:

$$
\begin{aligned}
& \mathrm{CH}_{4}=\mathrm{CH}_{3(\mathrm{a})}+\mathrm{H}_{(\mathrm{a})} \\
& \mathrm{CO}_{2}+\mathrm{H}_{(\mathrm{a})}=\mathrm{CO}+\mathrm{OH}_{(\mathrm{a})} \\
& \mathrm{CH}_{4}+\mathrm{O}_{(\mathrm{a})}=\mathrm{CH}_{3(\mathrm{a})}+\mathrm{OH}_{(\mathrm{a})} \\
& \mathrm{CH}_{3(\mathrm{a})}=\mathrm{CH}_{2(\mathrm{a})}+\mathrm{H}_{(\mathrm{a})} \\
& \mathrm{CH}_{2(\mathrm{a})}=\mathrm{CH}_{(\mathrm{a})}+\mathrm{H}_{(\mathrm{a})} \\
& \mathrm{CH}_{x(\mathrm{a})}=\mathrm{C}+x \mathrm{H}_{(\mathrm{a})} \\
& \mathrm{CH}_{x}+\mathrm{O}_{(\mathrm{a})}=\mathrm{CO}+x \mathrm{H}_{(\mathrm{a})} \\
& \mathrm{CH}_{x(\mathrm{a})}+\mathrm{CO}_{2}=2 \mathrm{CO}+x \mathrm{H}_{(\mathrm{a})} \\
& 2 \mathrm{H}_{(\mathrm{a})}=\mathrm{H}_{2(\mathrm{~g})} \\
& 2 \mathrm{OH}_{(\mathrm{a})}=\mathrm{H}_{2} \mathrm{O}+\mathrm{O}_{(\mathrm{a})}
\end{aligned}
$$

Whereas the decomposition of methane on supported palladium in the absence of carbon dioxide produces a multilayer of carbon at the reaction temperature (Table 1 ), in the hightemperature reaction of $\mathrm{CO}_{2}+\mathrm{CH}_{4}$ only a limited amount of surface carbon was produced. This suggests that the reactions of $\mathrm{CH}_{x(\mathrm{a})}$ fragments with $\mathrm{CO}_{2}$ and $\mathrm{O}_{(\mathrm{a})}$ are very efficient; in other words, the possibility of decomposition of $\mathrm{CH}_{x}$ to the surface carbon is limited. Alternatively, the carbon ("status nascendi") formed in the methane dissociation reacts with carbon dioxide and/or water immediately after its production,

$$
\begin{aligned}
& \mathrm{C}+\mathrm{CO}_{2}=2 \mathrm{CO} \\
& \mathrm{C}+\mathrm{H}_{2} \mathrm{O}=\mathrm{CO}+\mathrm{H}_{2}
\end{aligned}
$$

before its aging and transformation into a less reactive form. Although we can not decide between the two alternatives at this stage of our work, we believe that the second alternative is less likely.

The fact that the ratio $\mathrm{CO} / \mathrm{H}_{2}$ was always higher than 1 , and that it varied with the temperature and the catalyst, indicate the occurrence of several secondary processes, e.g. the hydrogenation of carbon monoxide and carbon dioxide, in this complex system. We note that the calculated equilibrium $\mathrm{CO} / \mathrm{H}_{2}$ ratio at $800 \mathrm{~K}$ is 1.65 , and the conversions of methane and $\mathrm{CO}_{2}$ are $20.6 \%$ and $30.8 \%$, respectively [6]. 
The variation of the $\mathrm{CO} / \mathrm{H}_{2}$ ratio with the catalyst sample and with the temperature is probably due to the differences in the activation energy of the secondary reactions. For example the activation energy for methane formation in the $\mathrm{H}_{2}+\mathrm{CO}_{2}$ reaction is much higher on $\mathrm{Pd} / \mathrm{MgO}(156.1 \mathrm{~kJ} / \mathrm{mol})$ than on the other samples $(81-103 \mathrm{~kJ} / \mathrm{mol})[14,15]$. In contrast, the activation energies for methane formation in the $\mathrm{H}_{2}+\mathrm{CO}$ reaction on the same catalyst were lower and differed only slightly from each other $[14,15]$.

The rate of the $\mathrm{CO}_{2}+\mathrm{CH}_{4}$ reaction on the palladium catalyst was very sensitive to the nature of the support. This is in contrast to the case of supported rhodium where no significant effect was established [12]. The specific activity of $\mathrm{Pd} / \mathrm{TiO}_{2}$ exceeded by almost one order of magnitude that of the less active $\mathrm{Pd} / \mathrm{MgO}$ and $\mathrm{Pd} / \mathrm{SiO}_{2}$ ( Table 2). The $\mathrm{Pd} / \mathrm{TiO}_{2}$ exhibited a higher activity even when it was reduced at $723 \mathrm{~K}$, below the temperature of the development of the so-called "SMSI" effect. Similar results were obtained in the hydrogenation of carbon monoxide and carbon dioxide on supported palladium [14,15]. The order of activity of the palladium samples may be related to their efficiency in the dissociation of carbon dioxide, where the same order of activity was found. Accordingly in the case of supported palladium, the activation of carbon dioxide should play an important role in the $\mathrm{CH}_{4}+\mathrm{CO}_{2}$ reaction. The high activity of $\mathrm{Pd} / \mathrm{TiO}_{2}$ may be associated with the extended electronic interaction between $\mathrm{Pd}$ and n-type $\mathrm{TiO}_{2}$ [32] which increases the back donation of electrons from the palladium into $\pi$ bonding of carbon dioxide thereby facilitating its dissociation and the formation of reactive oxygen required for the activation and reaction of methane. Alternatively, the oxygen vacancy present on titania promotes the dissociation of carbon dioxide.

\section{Conclusions}

(i) Methane decomposes on supported palladium samples at 773 to give hydrogen, a small amount of ethane and a carbonaceous residue. On $\mathrm{Pd} / \mathrm{SiO}_{2}$, the formation of ethylene was also observed. (ii) The carbon formed in the high temperature decomposition of methane is rather unreactive and hydrogenated only above $720 \mathrm{~K}$. (iii) The dissociation of carbon dioxide occurred at elevated temperatures on all the palladium samples to give adsorbed carbon monoxide of different coordinations. In this case a significant support effect was established. The addition of $\mathrm{CH}_{4}$ to $\mathrm{CO}_{2}$ promoted the dissociation process. (iv) Supported palladium is an active catalyst in the high temperature reaction of $\mathrm{CO}_{2}+\mathrm{CH}_{4}$ giving hydrogen and carbon monoxide with no or only very little carbon deposition. The order of activity of the catalysts, based on the turnover frequencies, is $\mathrm{Pd} / \mathrm{TiO}_{2}>\mathrm{Pd} /$ $\mathrm{Al}_{2} \mathrm{O}_{3}>\mathrm{Pd} / \mathrm{SiO}_{2}>\mathrm{Pd} / \mathrm{MgO}$.

\section{Acknowledgement}

Financial support of this work by OTKA (contact number 2038) and a loan of palladium chloride from Johnson-Matthey are gratefully acknowledged. 


\section{References}

I D.M. Bibby, C.D. Chang, R.F. Howe and S. Yurchak (Editors), Methane Conversion, (Studies in Surface Science and Catalysis, Vol. 36), Elsevier, Amsterdam, 1988.

2 J.H. Lunsford, in L. Guczi, F. Solymosi and P. Tétényi (Editors), Proc. of 10th Intern. Congress in Catalysis, Akadémiai Kiadó, Budapest, 1993, p. 103.

3 W.M. Ayers (Editor), Catalytic Activation of $\mathrm{CO}_{2}$, ACS Symp. Ser., Am. Chem. Soc., Washington, DC, 1988.

4 S. Teuner, Hydrocarbon Process., 64 ( 1985$) 106$.

5 J.T. Richardson and S.A. Paripatyadar, Appl. Catal., 61 (1990) 293.

6 J. Varga and V. Hesp, Acta Chim. Hung., 3 ( 1953) 209.

7 O. Tokunaga and S. Ogasawara, React. Kinet. Catal. Lett., 39 ( 1989) 70.

8 Y. Sakai, H. Saito, T. Sodesawa and F. Nozaki, React. Kinet. Catal. Lett., 24 (1984) 253.

9 T. Sodesawa, A. Dobashi and F. Nozaki, React. Kinet. Catal. Lett., 12 ( 1979) 107.

10 M. Masai, H. Kado, A. Miyake, S. Nishiyama and S. Tsuruya, in D.M. Bibby, C.D. Chang, R.F. Howe and S. Yurchak (Editors), Methane Activation, (Studies in Surface Science and Catalysis, Vol. 36), Elsevier, Amsterdam, 1987, p. 67.

11 F. Solymosi, Gy. Kutsán and A. Erdöhelyi, Catal. Lett., II (1991) 149.

12 A. Erdöhelyi, J. Cserényi and F. Solymosi, J. Catal., 141 ( 1993$) 287$.

13 A.T. Ashcroft, A.K. Cheetham, M.L.H. Green, and P.D.F. Vernon, Nature, 352 ( 1991 ) 225.

14 A. Erdöhelyi, M. Pásztor and F. Solymosi, J. Catal., 98 (1986) 166.

15 F. Solymosi, A. Erdöhelyi and M. Lancz, J. Catal., 95 ( 1985 ) 567.

16 F. Solymosi and A. Berkó, Surf. Sci., 171 (1986) L498.

17 F. Solymosi and A. Berkó, J. Catal., 101 (1986) 458.

18 S. Wohlrab, D. Ehrlich, J. Wambach, H. Kuhlenbeck and H. Freund, Surf. Sci., 220 ( 1989) 243.

19 F. Solymosi, J. Mol. Catal., 65 (1991) 337.

20 A. Palazov, C.C. Chang and R.J. Kokes, J. Catal., 36 (1971) 338.

21 A.M. Bradshaw and F.M. Hoffmann, Surf. Sci., 72 (1978) 513.

22 R.F. Hicks, Q.J. Yen and A.T. Bell, J. Catal., 89 (1984) 498.

23 R.P. Beebe and J.T. Yates, Surf. Sci., 173 (1986) L606.

24 F. Solymosi and M. Pásztor, J. Phys. Chem. 89 ( 1985 ) 4783.

25 F. Solymosi and M. Pásztor, J. Phys. Chem., 90 (1986) 5312.

26 F. Solymosi and H. Knözinger, J. Chem. Soc. Faraday Trans., 86 ( 1990) 389.

27 F. Solymosi, A. Erdöhelyi and J. Cserényi, Catal. Lett., 16 ( 1992$) 399$.

28 F. Solymosi and A. Erdöhelyi, Surf. Sci., 110 ( 1981 ) L630.

29 A. Erdöhelyi and F. Solymosi, J. Catal., 84 (1983) 446.

30 F. Solymosi, A. Erdöhelyi and M. Kocsis, J. Catal., 65 (1980) 428.

31 F. Solymosi, A. Erdöhelyi and T. Bánsági, J. Chem. Soc., Faraday Trans. I., 77 ( 1981 ) 2645.

32 F. Solymosi, Catal. Reviews, I (1968) 233. 